\title{
12: 68150453-68255011
}

National Cancer Institute

\section{Source}

National Cancer Institute. 12:68150453-68255011. NCI Thesaurus. Code C42339.

Physical location of FRS2_Gene 